\title{
Identification of cultivable heat tolerant wheat genotypes suitable for Patuakhali district in Bangladesh
}

\author{
M. Z. Haque, M. M. Hasan, M. M. R. Rajib ${ }^{1}$ and M. M. Hasan \\ Department of Agricultural Botany and ${ }^{1}$ Department of Horticulture, Patuakhali Science and Technology University, \\ Dumki, Patuakhali-8602
}

\begin{abstract}
Fifteen wheat genotypes namely Agrani, Prodip, Bijoy, CB 69, Sourav, Sufi, BAW 1064, Gourab, Kanchan Shatabdi, CB 30, Sonora, CB 24, CB34, and Protiva were sown under optimum (Nov. 30) and late (Dec. 30) sowing times to evaluate their performances at high temperature depending on cell membrane thermostability and some morphophysiological characters. Based on cell membrane thermostability test four genotypes showed the longest heat killing time and were separated as heat tolerant (HT). Four genotypes showed the shortest heat killing time and were separated as heat sensitive (HS). The remaining seven genotypes required time in between those two were separated as intermediate heat tolerant (IHT) genotypes. Lower contribution of photosynthate stem reserves (PSR) to grain in HT genotypes finally contributed to its less affected 1000-grain weight as well as yield. These results suggest that greater cell membrane thermostability supported the minimal changes in some physiological characters of HT ganotypes which ultimately increased the wheat yield under short winter warmer condition.
\end{abstract}

Keywords: Membrane thermostability, Wheat genotype

\section{Introduction}

Wheat (Triticum aestivum $\mathrm{L}$ ) is an important cereal crop in Bangladesh as well as in the world. It ranks first globally and second most important cereal next to rice in Bangladesh in terms of production and acreage (BBS, 2007 and FAO, 1999). In 2006-07, wheat covered an area of about 0.67 million hectare of land and produced 0.74 million tons of grain (BBS, 2007). But the actual yield (about $2 \mathrm{t} / \mathrm{ha}$ ) is much of lower than its yield potential. This is due to many limiting factors of which high temperature stress is the vital physiological factors (Vijayalakshmi and Kolluru, 2007).

High temperature $\left(>30^{\circ} \mathrm{C}\right)$ at the time of grain filling is one of the major constraints in increasing productivity of wheat in tropical and sub-tropical countries (Rane and Nagarajan, 2004). A reduction of $28.9 \%$ grain yields of wheat was reported to in response of heat stress and heat stress caused a reduction of 8.5, 7.6, 5.6 percent for canopy temperature depression in 1000-grain weight, grain filling period and membrane injury (grain filling stage) respectively (Amandeep et al., 2007). With increase in stress intensity, a progressive and significant decrease was observed in yield and yield attributing traits in all wheat varieties (Singh et al., 2007). The study area is characterized by short winter environments resulting high temperature during reproductive stage of wheat which is most vulnerable period in response to heat. Therefore, there is an urgent need to emerge heat tolerant wheat genotypes and to asses their mechanism of heat tolerance under short winter warmer condition of Patuakhali district in Bangladesh.

\section{Materials and Methods}

The experiment was conducted at the agricultural farm of Patuakhali Science and Technology University during the period of November 2007 to April 2008. The experiment was conducted in a split-plot design with three replications. Fifteen genotypes of wheat (Triticum aestivum L.) namely Agrani, Prodip, Bijoy, CB 69, Sourav, Sufi, BAW 1064, Gourab, Kanchan, Shatabdi, CB 30, Sonora, CB 24, CB34, and Protiva were selected as experimental material. Two dates of sowing viz. $S_{1}=$ Optimum sowing time (30 November, 2007) and $S_{2}=$ Late sowing time (30 December, 2007) were selected.

Membrane thermostability was determined according to Ibrahim and Quick (2001). According to this method leaf sample were collected at anthesis from flag leaves of five randomly selected plants of each variety. From a flag leaf two leaf discs were collected using a leaf puncher $10.00 \mathrm{~mm}$ in diameter (LAT 162 Model Ronnd Open Industry Co. Ltd., Japan) and washed three times with deionized water to remove electrolytes adhering to leaf tissue, as well as electrolytes released from cut cells on the periphery of leaf discs. The test tubes were drained with deionized water also the leaf samples were then 
placed in $25 \mathrm{~mm} \times 150 \mathrm{~mm}$ test tubes and a piece of cotton was put on the leaf disc inside the test tube to prevent any injury of the leaf discs by the electrode bar during the conductance measurement. Thereafter $20 \mathrm{ml}$ of deionized water was added. Then the initial conductivity readings (I) were taken with an electric conductivity (EC) meter (Wintec Conductivity Meter, Model Japan). The test tubes were covered by aluminum foil and placed in a thermostatically controlled water bath (Model SM-05, Taitec, Japan) maintaining a constant temperature of $55^{\circ} \mathrm{C}$. Electrical Conductivity reading (E) was taken every 30 minutes up to 4 hours at an elevated temperature of $55^{\circ} \mathrm{C}$. The test tube samples were then autoclaved, held at a pressure to $0.10 \mathrm{Mpa}$ for 10 minutes to completely kill plant tissue and release all the electrolytes. After autoclaving the samples were again placed in a water bath $a t 55^{\circ} \mathrm{C}$ to adjust the elevated temperature and after 30 minutes the incubation, final conductance $(F)$ was measured. The percentage injury induced by the elevated temperature during the time course (30 minutes) was calculated as follows:

According to this method percent injury was calculated by the following formula:

$\operatorname{Injury}(\%)=\frac{E-I}{F} \times 100$

Where,

I = The initial conductance

$\mathrm{E}=$ The elevated temperature conductance

$\mathrm{F}=$ The final conductance after autoclaving

By using this formula the percent membrane injury levels were determined at different duration (every 30 min staring from $60 \mathrm{~min}$ to $240 \mathrm{~min}$ ) under two sowing times $\left(\mathrm{S}_{1}\right.$ and $\left.\mathrm{S}_{2}\right)$. These percent injury levels also determined the heat killing time of particular genotypes. Though these injury levels were percentage record, analysis were not done following statistical process.

Photosynthate stem reserve translocation (PSR) was calculated according to Gallagher et al. (1975). After four weeks of sowing, the main stem was marked by colored thread for easy identification of the subsequent sampling. Five main stems were taken from each plot as sample at anthesis as well as at final harvest for measuring ear and stem weight. After collection, both ear and stem were dried at $72^{\circ} \mathrm{C}$ for 48 hours and weighed. After drying samples were weighed.

This is based on the net loss in weight of above ground vegetative organs between anthesis and maturity with the differences between yield and net assimilation. It was calculated as-

PSR translocation $(\%)=\frac{S_{1}-S_{2}}{G_{1}-G_{2}} \times 100$

Where,

$\mathrm{S}_{1}=$ Stem dry weight $(\mathrm{g})$ at anthesis

$\mathrm{S}_{2}=$ Stem dry weight $(\mathrm{g})$ at maturity

$\mathrm{G}_{1}=$ Grain dry weight $(\mathrm{g})$ at anthesis

$\mathrm{G}_{2}=$ Grain dry weight $(\mathrm{g})$ at maturity

Relative performance was measured by the ratio of late sowing (December 30) performance to optimum sowing (November 30 ) performance which was expressed in percentage and was calculated as follows-

Relative performance $(\%)=\frac{\text { Late sowing peformance }}{\text { Optimum sowing performance }} \times 100 \times 100$

1000-grain weight was measured by randomly taken thousand grains from each plot and the total weight was recorded and the moisture content was adjusted to $12 \%$ as cereal grain.

Grain yield was calculated by collecting grains of $1 \mathrm{~m}^{2}$ area. Finally, it was converted to one hectare and expressed in tons. 
Statistical analysis was done by using MSTAT-C statistical program. The treatment means were compared using Duncan's Multiple Range test (DMRT) at $5 \%$ level of significance (Gomez and Gomez, 1984).

\section{Results and Discussion}

\section{Cell membrane thermostability}

Cell membrane thermostability differed among the wheat genotypes under both optimum and late sowing heat stressed condition. Time required to reach 50\% membrane injury in a genotype was considered to be its heat killing time. The longest heat killing time $(240 \mathrm{~min})$ was observed in Agrani whereas Sonora required lowest heat killing time (75 min.) (Table 1 and Fig. 1). Based on cell membrane thermostability (CMT) test, four genotypes (Agrani, CB 30, Kanchan and CB 69) showed the longest heat killing time (between 210 and $240 \mathrm{~min}$ ) and were categorized as heat tolerant (HT) (Table 1 and Fig. 1). In addition, four genotypes (Sonora, CB 24, CB 34 and Protiva) attained the shortest heat killing time (between 75 and $105 \mathrm{~min}$ ) and were designed as heat sensitive (HS) (Table 1 and Fig 1). The remaining seven genotypes (Sourav, Sufi, BAW 1064, Gourab, Prodip, Shatabdi and Bijoy) attained intermediate heat killing time (between 120 and $165 \mathrm{~min}$ ) and were categorized as intermediate heat tolerant (IHT) genotypes (Fig. 1). The average daily air temperature during post-anthesis period was $24.90^{\circ} \mathrm{C}$ under optimum sowing time whereas during the late sowing time it was $27.48^{\circ} \mathrm{C}$ (Fig. 2). This implies that, late seeded wheat of this district faced about $3^{0} \mathrm{C}$ higher temperature than optimum sowing at post anthesis. This result also agrees with Haque (2002) who pointed higher mean heat killing time in HT genotypes at CMT test.

Table 1. Per cent of membrane injury and heat killing time of flag leaf tissues at different times of elevated temperature $\left(55^{\circ} \mathrm{C}\right)$ in fifteen wheat genotypes grown under optimum and late sowing times

\begin{tabular}{|c|c|c|c|c|c|c|c|c|c|c|c|c|c|c|}
\hline \multirow{3}{*}{ Genotypes } & \multicolumn{14}{|c|}{ Per cent Injury at different exposed time (minute) at $55{ }^{\circ} \mathrm{C}$} \\
\hline & \multicolumn{7}{|c|}{ Optimum sowing time } & \multicolumn{7}{|c|}{ Late sowing time } \\
\hline & 60 & 90 & 120 & 150 & 180 & 210 & 240 & 60 & 90 & 120 & 150 & 180 & 210 & 240 \\
\hline Agrani & 33.19 & 40.26 & 42.22 & 44.02 & 47.03 & 49.73 & 53.61 & 27.62 & 33.95 & 37.59 & 39.18 & 44.38 & 48.27 & 51.90 \\
\hline Prodip & 41.46 & 44.61 & 47.83 & 55.13 & 62.33 & 67.11 & 72.00 & 38.52 & 42.18 & 48.38 & 56.31 & 60.81 & 66.30 & 69.85 \\
\hline Bijoy & 36.40 & 43.28 & 47.57 & 54.82 & 65.79 & 72.25 & 74.34 & 31.61 & 37.19 & 43.93 & 49.63 & 54.12 & 60.31 & 68.17 \\
\hline CВ 69 & 29.82 & 35.34 & 39.19 & 43.58 & 47.41 & 52.38 & 55.18 & 27.34 & 34.80 & 37.87 & 42.19 & 46.30 & 52.93 & 58.89 \\
\hline Saurav & 38.39 & 43.14 & 47.88 & 52.33 & 59.21 & 63.18 & 66.38 & 36.16 & 40.31 & 48.19 & 53.14 & 58.41 & 62.38 & 68.13 \\
\hline Sufi & 36.95 & 47.86 & 59.71 & 63.62 & 68.04 & 71.12 & 72.87 & 31.79 & 38.51 & 44.64 & 51.23 & 58.13 & 60.12 & 63.23 \\
\hline BAW 1064 & 41.46 & 44.61 & 48.21 & 51.96 & 58.23 & 62.02 & 67.09 & 34.33 & 40.36 & 46.89 & 52.98 & 58.123 & 60.14 & 65.34 \\
\hline Gourab & 41.46 & 48.39 & 54.26 & 61.17 & 66.31 & 68.31 & 71.36 & 38.64 & 47.93 & 56.62 & 60.71 & 63.13 & 66.38 & 70.32 \\
\hline Kanchan & 28.37 & 35.30 & 39.83 & 43.53 & 46.94 & 51.46 & 57.73 & 26.64 & 33.06 & 36.34 & 41.30 & 45.41 & 52.84 & 56.31 \\
\hline Shatabdi & 37.80 & 46.41 & 57.69 & 69.38 & 78.14 & 81.12 & 82.14 & 35.78 & 47.92 & 58.96 & 67.83 & 80.14 & 83.38 & 85.41 \\
\hline CB 30 & 35.13 & 38.91 & 42.85 & 44.23 & 46.13 & 49.12 & 52.16 & 31.09 & 34.69 & 41.79 & 43.89 & 46.17 & 48.78 & 52.19 \\
\hline Sonora & 54.16 & 62.66 & 67.31 & 73.71 & 76.08 & 78.19 & 79.39 & 44.12 & 52.36 & 59.03 & 64.12 & 68.81 & 70.32 & 72.13 \\
\hline CB 24 & 51.38 & 58.75 & 65.51 & 70.16 & 72.68 & 73.68 & 77.42 & 44.28 & 51.60 & 61.28 & 66.38 & 68.16 & 71.42 & 73.24 \\
\hline CB 34 & 44.62 & 52.74 & 56.43 & 62.13 & 69.71 & 73.14 & 76.34 & 43.12 & 47.73 & 54.76 & 60.83 & 62.05 & 66.43 & 71.76 \\
\hline Protiva & 42.13 & 50.28 & 54.28 & 58.41 & 62.98 & 68.13 & 75.73 & 44.31 & 53.12 & 56.82 & 63.14 & 68.89 & 72.21 & 76.31 \\
\hline
\end{tabular}




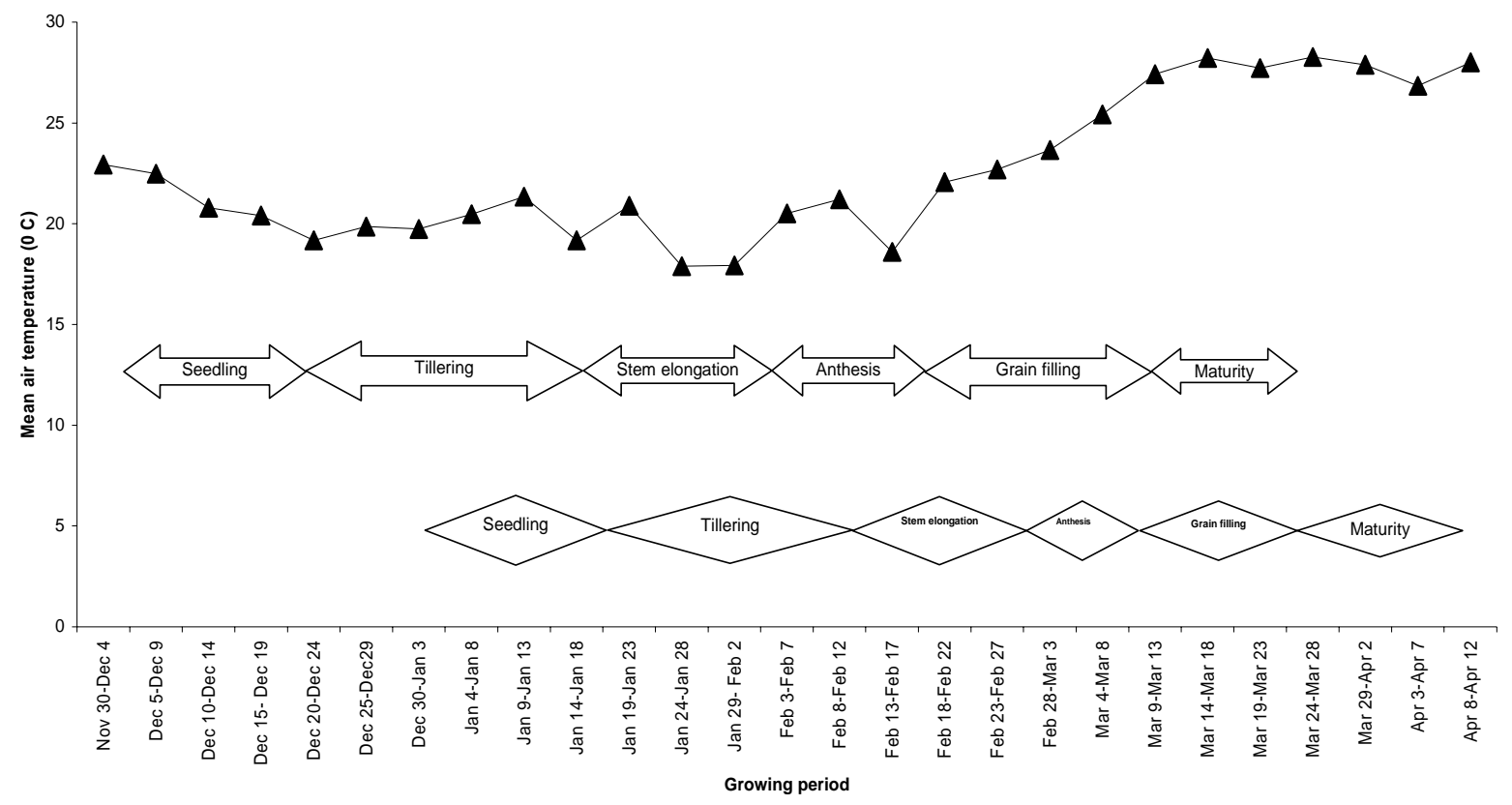

Fig. 1. Mean time to attain $50 \%$ membrane injury through cell membrane thermostability (CMT) test in fifteen wheat genotypes sown under optimum and late sowing time

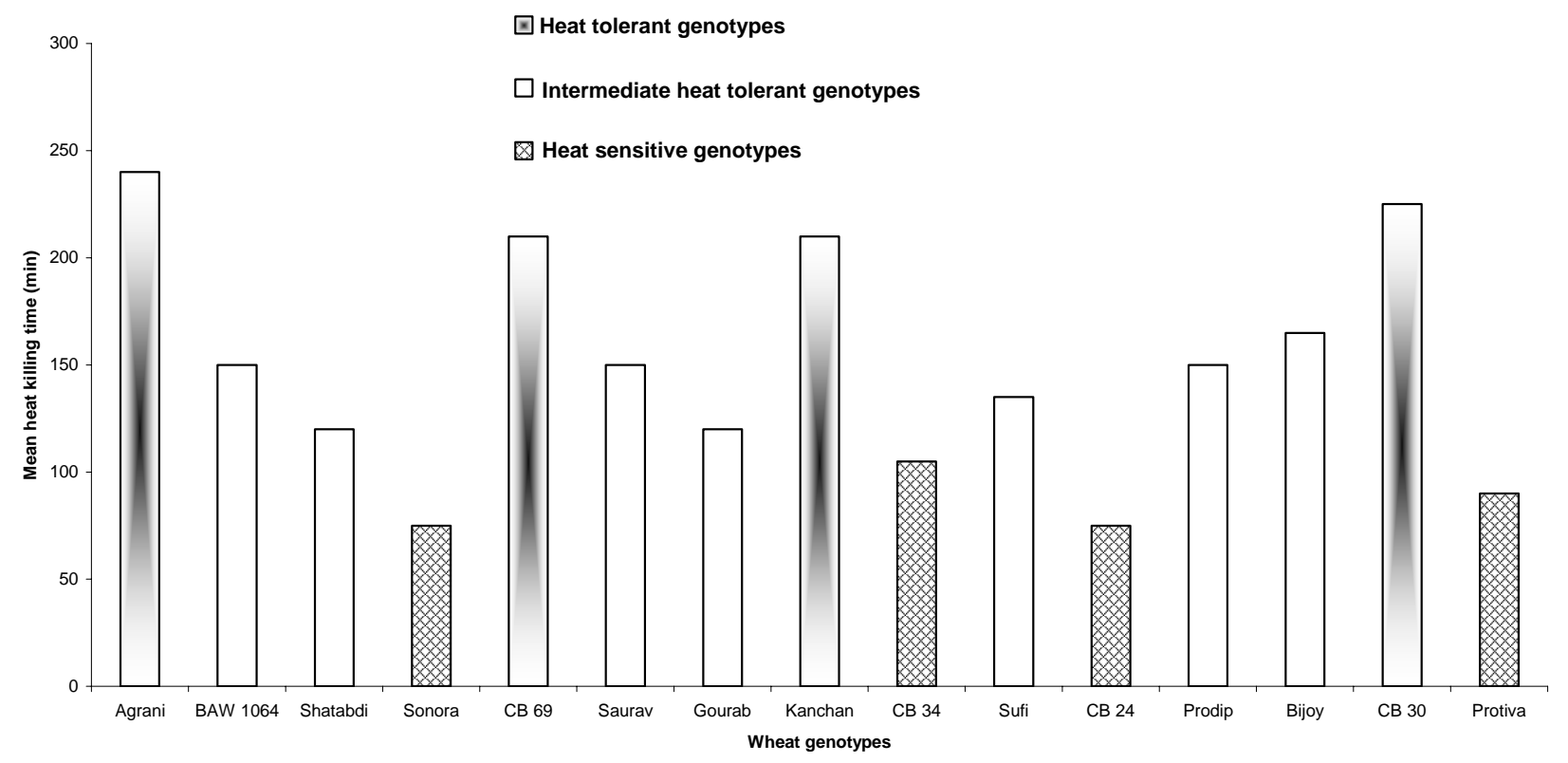

Fig. 2. Mean air temperature received by fifteen wheat genotypes from seedling to maturity under optimum and late sowing times (data source: Patuakhali A-graded weather observation centre)

\section{Photosynthate stem reserve translocation}

Photosynthate stem reserve translocation (PSR) from stem to grain in HT genotypes varied from 20.57 to $32.05 \%$ in optimum sowing time whereas, it was 28.45 to $34.95 \%$ in late sowing time. In case of HS genotypes under optimum and late sowing time the variation ranged from 20.10 to $25.80 \%$ and 34.55 to $41.25 \%$ respectively (Table 2). During stress condition, the highest PSR $(41.25 \%)$ was observed in the wheat genotype CB 34. Result revealed that HT genotypes tend to adapted in heat stressed environment by lessening PSR translocation to grain. Stem reserves contribution to final grain weight was to be increased under stressed conditions in wheat (Sikder et al., 1999). 
Table 2. Pre-anthesis photosynthate stem reserve (PSR) translocation, 1000-grain weight and grain yield of wheat as affected by growing conditions and genotypes

\begin{tabular}{|c|c|c|c|c|c|c|c|c|c|}
\hline \multirow{2}{*}{$\begin{array}{l}\text { Heat tolerant } \\
\text { groups }\end{array}$} & \multirow[b]{2}{*}{ Genotypes } & \multicolumn{2}{|c|}{$\begin{array}{c}\text { Per cent of } \\
\text { pre-anthesis } \\
\text { PSR contribution } \\
\text { to grain }\end{array}$} & \multicolumn{3}{|c|}{$\begin{array}{l}\text { 1000-grain weight } \\
\text { (g) }\end{array}$} & \multicolumn{3}{|c|}{$\begin{array}{l}\text { Grain yield } \\
\text { (t/ha) }\end{array}$} \\
\hline & & $\begin{array}{l}\text { Optimum } \\
\text { sowing } \\
\text { time }\end{array}$ & $\begin{array}{l}\text { Late } \\
\text { sowing } \\
\text { time }\end{array}$ & $\begin{array}{l}\text { Optimum } \\
\text { sowing } \\
\text { time }\end{array}$ & $\begin{array}{l}\text { Late } \\
\text { sowing } \\
\text { time }\end{array}$ & $\begin{array}{c}\text { Relative } \\
1000- \\
\text { grain } \\
\text { weight } \\
(\%)\end{array}$ & $\begin{array}{l}\text { Optimum } \\
\text { sowing } \\
\text { time }\end{array}$ & $\begin{array}{l}\text { Late } \\
\text { sowing } \\
\text { time }\end{array}$ & $\begin{array}{c}\text { Relative } \\
\text { grain yield } \\
(\%)\end{array}$ \\
\hline \multirow{4}{*}{ Heat tolerant } & Agrani & 26.15 & 28.45 & $44.83 b$ & $38.78 d$ & 86.50 & $3.58 \mathrm{~cd}$ & $2.52 \mathrm{k}$ & 70.39 \\
\hline & Kanchan & 20.57 & 31.09 & $46.93 a$ & $36.84 \mathrm{ef}$ & 82.76 & $3.71 a b$ & $2.32 \mathrm{~m}$ & 62.53 \\
\hline & CB 30 & 27.32 & 30.12 & $44.62 b c$ & 37.98de & 84.96 & 3.51de & 2.411 & 68.66 \\
\hline & CB 69 & 32.05 & 34.95 & $44.16 \mathrm{bc}$ & $36.17 f$ & 81.90 & $3.76 a$ & $2.24 \mathrm{mn}$ & 59.57 \\
\hline \multirow{7}{*}{$\begin{array}{c}\text { Intermediate } \\
\text { Heat } \\
\text { Tolerant }\end{array}$} & Saurav & 26.75 & 27.50 & $43.63 b c$ & 33.73ghi & 77.30 & $3.21 \mathrm{~h}$ & $1.79 q$ & 55.76 \\
\hline & Sufi & 24.95 & 25.88 & $43.23 c$ & $32.68 \mathrm{ij}$ & 75.59 & $3.56 \mathrm{~d}$ & 2.040 & 57.30 \\
\hline & BAW 1064 & 27.90 & 31.82 & $43.81 b c$ & $34.26 \mathrm{gh}$ & 78.20 & $3.30 \mathrm{~g}$ & 1.97op & 58.33 \\
\hline & Gourab & 24.05 & 22.39 & $44.15 b c$ & $32.43 i j$ & 73.45 & $3.46 \mathrm{ef}$ & $1.71 q$ & 49.42 \\
\hline & Prodip & 25.48 & 24.70 & $43.56 \mathrm{bc}$ & 33.23hij & 76.29 & $3.31 \mathrm{~g}$ & $1.90 p$ & 57.40 \\
\hline & Shatabdi & 23.57 & 26.75 & $44.36 \mathrm{bc}$ & $32.17 \mathrm{j}$ & 72.52 & $3.39 \mathrm{fg}$ & $1.58 r$ & 46.61 \\
\hline & Bijoy & 28.65 & 33.17 & $43.92 b c$ & $34.84 \mathrm{~g}$ & 79.30 & $3.66 \mathrm{bc}$ & $2.21 n$ & 60.38 \\
\hline \multirow{4}{*}{$\begin{array}{c}\text { Heat } \\
\text { Sensitive }\end{array}$} & Sonora & 20.1 & 34.55 & $37.15 \mathrm{ef}$ & $24.16 \mathrm{~m}$ & 65.03 & $2.61 \mathrm{j}$ & $1.28 \mathrm{u}$ & 49.04 \\
\hline & CB 24 & 22.52 & 37.20 & 38.01de & $25.21 \mathrm{~m}$ & 66.21 & $2.98 \mathrm{i}$ & $1.34 \mathrm{tu}$ & 44.96 \\
\hline & CB 34 & 25.80 & 41.25 & $39.29 d$ & $27.43 \mathrm{k}$ & 69.81 & $2.48 \mathrm{kl}$ & $1.48 \mathrm{~s}$ & 51.38 \\
\hline & Protiva & 23.75 & 38.11 & $38.58 d$ & $26.16 \mid$ & 67.80 & $2.95 i$ & $1.41 \mathrm{st}$ & 47.80 \\
\hline $\begin{array}{c}\text { Level of } \\
\text { significance }\end{array}$ & - & \multicolumn{2}{|l|}{-} & \multicolumn{2}{|l|}{ - } & $\star \star$ & \multicolumn{2}{|c|}{ ** } & - \\
\hline CV \% & - & \multicolumn{2}{|l|}{ - } & \multicolumn{2}{|c|}{5.86} & - & \multicolumn{2}{|c|}{3.21} & - \\
\hline
\end{tabular}

** Significant at $1 \%$ level of significance

\section{0-grain weight}

Under optimum sowing time, the HT variety Kanchan showed the highest 1000-grain weight (46.93 g) which significantly differed with that of Agrani (44.83 g), CB $30 \quad(44.62 \mathrm{~g})$ and CB $69(44.16 \mathrm{~g})$ whereas, the HS genotype Sonora showed the lowest 1000-grain weight $(37.15 \mathrm{~g})$ under optimum sowing time (Table 2 ). Under late sowing time, HT genotypes showed weight in between $36.17 \mathrm{~g}$ in CB 69 to $38.78 \mathrm{~g}$ in Agrani, whereas HS genotypes ranged from $24.16 \mathrm{~g}$ in Sonora to $27.43 \mathrm{~g}$ in CB 34 (Table 2). Under late sowing time, both the HT and HS genotypes remarkably reduced their 1000-grain weight compared to optimum sowing time because they faced about $3^{\circ} \mathrm{C}$ more air temperature than optimum sowing during grain maturity (Fig. 2). Different amount of reduction in 1000-grain weight was due to difference in response of wheat genotypes to sowing times. The relative 1000-grain weight was higher in heat tolerant genotypes which ranged from 81.90 to $86.50 \%$ whereas, heat sensitive genotypes bared comparatively lower 1000-grain weight ranged from 37.15 to $38.58 \%$ ( Table 2). From the experiment result, it was reveled that 13.50 to $21.50 \%$ 1000-grain weight reduction occur in HT genotypes, whereas HS genotypes reduced 30.18 to $34.96 \%$ 1000-grain weight. However, these results are the indication about the responses of heat tolerant and heat sensitive wheat genotypes to high air temperature. 1000-grain weight reduction due to late sowing was also observed by Munjal and Dhanda (2004). Different wheat genotypes show reduction in grain weight in different rhythm due to higher air temperature during late sowing time (Haque, 2002).

\section{Grain yield}

Grain yield was significantly interacted by sowing times and genotypes. The result showed that under optimum sowing time, the tolerant variety CB 69 attained the highest grain yield (3.76 t/ha) and the HS genotype Sonora gave the lowest grain yield $(2.61 \mathrm{t} / \mathrm{ha})($ Table 2$)$. Under late sowing time heat tolerant variety Agrani produced highest grain yield (2.52 t/ha), while the sensitive variety Sonora showed the lowest grain yield (1.28 t/ha). Cargnin et. al. (2006) also found this kind of reduced yield under stress 
condition. Under late sowing time, the plant was exposed to high temperature during grain filling period compared to optimum sowing. CB 69 showed higher yield potential in optimum sowing time than Agrani while Agrani showed both yield and tolerance potential as it obtained higher yield in heat stressed condition. Results from other studies showed that late sowing caused lower grain yield of wheat genotypes compared to optimum sowing (Islam et al. 1993,).

Among all the tested genotypes, four genotypes namely Agrani, Kanchan, CB 30, CB 69 were found as HT genotypes for cultivation in Patuakhali district. But four namely Sonora, CB 34, CB 24 and Protiva were found as heat sensitive genotypes for the same. The remaining seven genotypes performed intermediate position in MT test. PSR was slightly increased in HT genotypes during late sowing time compared to optimum sowing time. On the other hand, in HS genotypes PSR was greatly increased in late sowing time. In case of 1000-grain weight HT genotypes showed minimal reduction under heat stressed condition. So, the evaluated attributes of HT genotypes such as high heat killing time, lower PSR translocation and higher 1000-grain weight ultimately contribute the supportive to high yield of CB 69, Agrani as HT genotypes.

\section{References}

Amandeep, K., Sohu, V.S. and Mavi, G.S. 2007. Genotypic variation for physiological traits associated with heat tolerance in bread wheat (Triticum aestivum L.). Crop. Improvement, 34(2): 117-123.

Bangladesh Burea of Statistics (BBS). 2007. Statistical year book of Bangladesh. Statistical Division, Ministry of Planning. Govt. of the peoples Republic of Bangladesh, Dhaka.

Cargnin, A., Souza M.A., Rocha V.S., Machado J.C. and Piccini, E. 2006. Tolerance to thermic stress in wheat genotypes. Pesquisa Agropecuaria Brasileira, 41 (8): 1269-1276.

Food and Agricultural Organization (FAO). 1999. Production Year Book. An Appraisal of Seed Biology and the Yield of Grain Crops. Cab. International, pp.112-121.

Gallagher, J.N., Biscoe, P.V. and Scott, R.K. 1975. Barley and its environment. 20V. Stability of grain weight. J. App. Ecol., 21: 319336.

Gomez, K.A. and Gomez., A.A.1984. Statistical Procedure for Agricultural Research,2nd edition. A wiley Interscience Pub., John wiley and Sons,New York.p.628.

Haque, Z.M. 2002. Heat tolerant characteristics of wheat under late seeded condition. MS Thesis, Department of Crop Botany, Bangabandhu Sheikh Mujibur Rahman Agricultural University, Salna, Gazipur. Pp 49-59.

Ibrahim, A.M.H. and Quick, J.S. 2001b. Genetic control of high temperature tolerance in wheat as measured by membrane thermostability. Crop Sci. 41: 5, 1405-1407.

Islam, N., Ahmed S.M., Razzaque M.A., Sufian A. and Hossain M.A. 1993. A study on the effect of seedling dates on the yield of wheat varieties. Bangladesh J. Agril. Res., 18(1): 102-107.

Munjal, R. and Dhanda S.S. 2004. Associations for heat tolerance in bread wheat. National J. Plant Improvement, 6 (1): 71-73.

Rane, J. and Nagarajan, S. 2004. High temperature index-for field evaluation of heat tolerance in wheat varieties. Agricultural Systems, 79(2):243-255.

Sikder, S., Ahmed, J.U., Hossain. T., Mian M.A.K. and Hossain. M.M. 1999. Membrane thermostability, grain growth and contribution of pre-anthesis stem reserves to grain weight of wheat under late seeded conditions. Thai J. Agril. Sci., 32 (4): 465-473.

Singh, J.P., Shambhoo P., Singh K.N., and Randhir S. 2007. Screening of heat tolerant wheat varieties by membrane thermostability index in relation to yield and yield attributing traits. Int. J. Plant Sci. Muzzaffarmagar, 2(2): 159-165.

Vijayalakshmi and Kolluru. 2007. Physiological and genetic analyses of post-anthesis heat tolerance in winter wheat (Triticum aestivum L.). Ann. Bot., 82 (2): 48-57. 